University of Nebraska - Lincoln

DigitalCommons@University of Nebraska - Lincoln

1955

\title{
Courtship Activities of the Anatidae in Eastern Washington
}

Paul A. Johnsgard

University of Nebraska-Lincoln, pajohnsgard@gmail.com

Follow this and additional works at: https://digitalcommons.unl.edu/biosciornithology

Part of the Ornithology Commons

Johnsgard, Paul A., "Courtship Activities of the Anatidae in Eastern Washington" (1955). Papers in Ornithology. 66.

https://digitalcommons.unl.edu/biosciornithology/66

This Article is brought to you for free and open access by the Papers in the Biological Sciences at DigitalCommons@University of Nebraska - Lincoln. It has been accepted for inclusion in Papers in Ornithology by an authorized administrator of DigitalCommons@University of Nebraska - Lincoln. 


\title{
COURTSHIP ACTIVITIES OF THE ANATIDAE IN EASTERN WASHINGTON
}

\author{
By PAUL A. JOHNSGARD
}

The many interesting and sometimes spectacular aspects of waterfowl courtship have been observed and recorded by several writers. Among the best and most complete descriptions are those of Bent $(1923,1925)$, Townsend $(1910,1916)$, Wetmore (1920), and Hochbaum (1944). However, for the most part these are unillustrated, deal with only a few species, or are based on limited observations.

In the summer of 1953 and the spring and summer of 1954 the writer did extensive field work in the Potholes Region of Grant County, Washington, gathering data for an ecological study of the birds and vegetation of that section. In the spring of 1954 he had occasion to observe epigamic activities of most species of waterfowl that are found in that region and was able roughly to delimit the periods of courtship and mating for several species. Determinations of sex-ratio for 15,434 waterfowl were made during the period from February 15 to May 15, 1954, and some of these data are presented in this paper, but a full discussion of the ratios and their significance will be deferred until a later time. The objectives of the present paper are to add descriptive material in the case of those species for which published observations are incomplete, to illustrate most of the basic actions seen, and to compare periods of courting among several species.

The area of study centers about a Columbia Basin Project dam, O'Sullivan Dam, and Potholes Reservoir. Adjacent to the reservoir is located a large area of sand dunes; between the bases of the dunes are found numerous potholes of various sizes. Below the dam seepage water has accumulated in many depressions and glacial-cut "scabland" channels, which usually remain open the year around. During the winter of 1953-54 many species of waterfowl wintered here, including all species discussed here except the Blue-winged Teal, Cinnamon Teal, and Barrow Goldeneye.

The four major ecological areas studied and roughly portrayed in figures 1 and 2 are as follows: (1) deep, rock-bound seepage lakes, in scabland channels (figs. 1D, 2C), on which Canvasbacks, goldeneyes, scaups, and Redheads often courted; (2) shallow seepage potholes below O'Sullivan Dam, which were usually bordered by sagebrush (Artemisia tridentata), and on which many species of surface-feeding ducks courted (fig. 1B); (3) the shore line, or "feather-edge" of Potholes Reservoir, adjacent to the sand dune potholes, where mergansers and Buffleheads often courted (fig. 2B, D); and (4) the sand dune potholes, where Ring-necked Ducks, Common Goldeneyes, Buffleheads, and some surface-feeding ducks courted (figs. 1A, 2A).

Before entering into descriptive accounts of each species, certain generalized observations may be presented. A surprising variation in time of courtship among various species was observed; Mallards, Pintails, Baldpates, and Gadwalls were nearly all paired by mid-February, while Ruddy Ducks did not begin pairing until mid-May. Species also varied greatly in regard to frequency and intensity of courtship activities. In general it may be said that the more disproportionate the sex-ratio, the more obvious and greatly extended the period of courtship display. Courting flights were not commonly observed except among scaups and Buffleheads. Certain species, notably the Bufflehead and Common Goldeneye, continued display activities well after it was apparent that the birds were already paired. Immature birds of these two species also actively engaged in courtship, although neither species mates until its second year (Kortright, 1942). In no case was an early migration of paired birds followed by a later migration of non-paired birds, although in several cases the opposite appeared to be true. 
Certain actions, illustrated in a single species, apply to a large group of waterfowl. These may be grouped into three classes, as follows:

Action typical of all species of waterfowl observed.-These include a "standing up" accompanied by a vigorous wing-flapping (fig. 1A, left background), and a "headdipping," which consists of a sudden dipping of the head into the water followed by rapid backward movement of the head to its normal upright position (fig. 1A, left background), causing water to flow down over the breast and back; this last is usually fol-

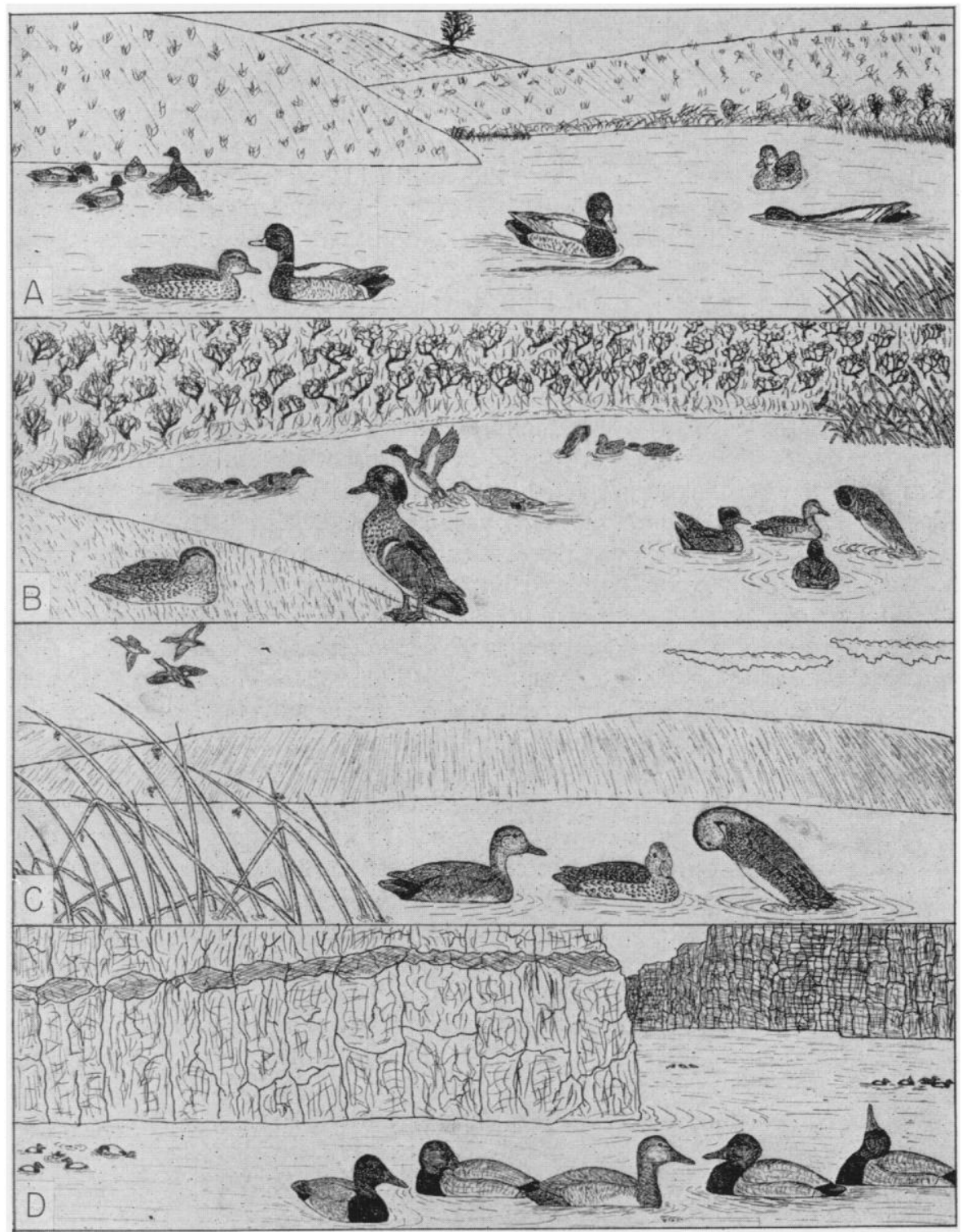

Fig. 1. Courtship mannerisms of the Mallard (A), Green-winged Teal (B), Gadwall (C), and Canvasback (D). 
lowed by a sidewise shaking of the tail. These actions may also be observed, usually to a lesser degree, during other periods of tension, as in territorial defense and brood protection. Preening (fig. 2D, left background) is commonly observed during courtship activities. Although both sexes indulge in these actions, the male does so more frequently.

Actions typical of surface-feeding ducks.-Head-bobbing, a deliberate up-anddownward movement of the head, is common to males of most surface-feeding ducks. Females respond in a similar manner. Bowing (fig. 1B, C) is practiced by males of many species of surface-feeding ducks.

Actions typical of diving ducks.- "Flock pursuit" (fig. 1D, 2A) is a characteristic action of most diving ducks, especially those of the genus Aythya. In this procedure a female leads a group of interested males in a vigorous and somewhat erratic chase; the female generally is in the lead. The "head-throw" (fig. 1D;2A, C), where the male suddenly throws his head backward until the occiput touches his back, followed by a vigorous return to its normal position, is characteristic of all the species of the genus Aythya that were observed. It is also seen in goldeneyes in a somewhat more exaggerated form.

The drawings are all based on sketches made in the field. Some are probably slightly incorrect due to the rapidity with which a few of the actions were carried out as well as to the artistic limitations of the writer.

Anas platyrhynchos. Mallard.-Courtship was observed three times between February 15 and 23, inclusive; copulation was observed on February 16 and 23. The majority of females were paired at the outset of field work in mid-February. Some birds were noted to be territorial by late February, and almost all females were paired by that time.

Townsend (1916) described well the courtship of this species, and only a short resumé will be given here. Early stages of courtship are characterized by the wing-flapping and head-dipping described earlier (fig. 1A, left background). Preliminary to copulation, the male begins a continuous and deliberate up and down head bobbing. The female soon begins a similar though less noticeable head movement (fig. 1A, left foreground), and shortly thereafter copulation takes place. This procedure is similar to that in all species observed, the female lying prone on the water with only the crown of her head above the surface (fig. 1A, center foreground), or sometimes with even this almost submerged. The male promptly mounts and the act is completed in a few seconds. Following copulation the male swims swiftly about in random circles, with the front of his body low in the water (fig. 1, right foreground). Both sexes then vigorously flap their wings and dip their heads in the manner previously described.

The sex-ratio remained stable throughout the period from February 15 to May 15, that of 4910 birds being 131 के 8 : $: 100 \% q$.

Anas acuta. Pintail.-Courtship was observed twice, on March 15 and April 12, although most birds were paired by mid-February. Typical actions include fighting among the males, head-dipping, and wing-flapping, but none of the bowing described by Bent (1923). Sometimes the female flies a short distance away from the fighting drakes, soon to be followed by them. Nearly all females were paired by the end of February, and some birds were territorial by early May.

The sex-ratio varied little throughout the period, that of 1049 birds being $126 \hat{\delta}$ o: 100 ㅇ․

Anas carolinensis. Green-winged Teal.--Courtship was observed four times in the period from February 21 to April 8. Copulation was observed on March 10. Paired birds were first recorded on February 22; most females were paired by mid-March. Territorial birds were first noted in late April. 
Little has been published on the courtship of this species, the account of Sutton, quoted by Bent (1923), being the only reference known to me. That description is based on a single observation and is quite different from the actions I observed. The observation of February 21 is typical of all those which have been witnessed. Two males and two females were seen on a small seepage pothole; one female was entirely ignored by the males. The usual sequence of actions was as follows: a male swam near the female, generally facing her, and then suddenly raised his body out of the water at about a forty-five degree angle, rapidly bringing his head downward until his bill touched his breast; simultaneously he raised his crest (fig. 1B, right foreground). He immediately returned to a sitting position, at which time he either waggled his tail, or, more commonly, stretched his head out directly forward (fig. 1B, right background); he then jerked his head far back to an upright position, at the same time raising his tail feathers and wings, still folded, over his back (fig. 1B, right foreground). The entire series of movements was done with great rapidity, requiring less than two or three seconds. This speed, plus the highly animated action of the bird, made it an amusing, although beautiful sight. The only noticeable reaction of the female to this was an occasional, fairly rapid forward and backward moving of her head, similar to that of a Coot (Fulica americana). Distance made it impossible to determine what noises, if any, were made during the performance. Occasionally a female chases away an intruding male (fig. 1B, center), and this victim often spends his wrath on another nearby male (fig. 1B, left).

The Green-winged Teal was the only species observed to engage in courtship on dry land. On April 8, five males and two females were observed in courtship, part of which was carried out on shore (fig. $1 \mathrm{~B}$, foreground). The actions of the males were the same as those described earlier, modified only slightly to fit the different conditions.

The sex-ratio of this species varied little through the spring period, that of 863 birds being 114:100.

Anas discors. Blue-winged Teal.-No courtship was observed; all birds were paired upon arrival on April 29. The sex ratio appeared to be even, that of 42 birds being 100:100. Ratios following May also remained equal until females began nesting.

The courtship has been described by Bennett (1938), and it appears to consist mainly of head-bobbing. This action is observed among pairs obviously already mated when a male approaches the mate of another male too closely; the mutual bobbing of heads is definitely a threat attitude. Head-bobbing is also observed in the summer among territorial birds. The species was noted to be territorial by early May.

Anas cyanoptera. Cinnamon Teal.-No courtship was observed by me. Almost all birds were paired upon arrival on April 10, and the sex-ratio until May 15 was nearly even, that of 114 birds being 97:100. As in the Blue-winged Teal, later migrants also were nearly all mated birds. The species was noted to be territorial by late April.

Dawson, quoted by Bent (1923), described the courtship, which seems similar to that of the Blue-winged Teal. Allen Greene of the United States Fish and Wildlife Service noted four males and three females courting on Lake Lenore National Wildlife Refuge, Grant and Douglas counties, on April 20 (personal communication).

Mareca americana. Baldpate.-No courtship was observed; paired birds were recorded in mid-February and most females were paired by the end of February. The sexratio was fairly disproportionate for surface-feeding ducks, that of 1054 birds being 140:100. Territorial birds were observed in early May.

Wetmore (1920) described the courtship, which takes place largely in the air.

Anas streperus. Gadwall.-Courtship was observed once, on February 22; most birds were paired at the outset of field work in mid-February. The single courtship observed took place in a shallow, reed-lined pothole and involved two males and a single female. 
The performance is similar to that described by Wetmore (1920) and consists of a courting flight (fig. 1C, left background) and a bowing display on the water (fig. 1C, foreground). The bow resembles that of the Green-winged Teal, but the Gadwall does not raise its body to so great an angle above the water, and the action is slower and more graceful. A high whistled peent usually accompanies each bow, and the female utters a low quack almost constantly. The feathers of the occipital region appear to be raised in an almost crest-like manner.

The sex-ratio was very nearly even throughout the migration period, that of 512 birds being 109:100. The species was noted to be territorial by early May.

Spatula clypeata. Shoveller.-Courtship was observed only once, on April 19; paired birds were first recorded on April 11, and most females were paired by late April. The sex-ratio was quite unbalanced during the entire period of migration, for 277 birds being 141:100.

The single courtship display observed consisted of a slow and deliberate head-bobbing by the four males and single female involved. This modest performance has been described by Millais (1902), and no elaboration seems necessary.

The species was first noted to be territorial in late April.

Aythya americana. Redhead.-Courtship was observed twice, on February 20 and April 9. Most females were paired in March. The sex-ratio for this species, based on 618 birds, was 152:100.

Observations of display were few, but the actions were similar to those described by Wetmore (1920). Displays consist mainly of the two actions most typical of diving ducks, the flock pursuit and the head-throw. Males actively participate in following unmated females about but only rarely perform the head-throw. No sounds, such as were described by Wetmore (1920), were heard by me, but distances at which observations were made were fairly great.

The species was observed to be territorial by early May.

Aythya valisineria. Canvasback.-Courtship was observed on seven occasions, from February 20 to March 15, by which latter date most birds departed. All females appeared unpaired during this time, although courtship was intense. The sex-ratio was highly unequal, that of 574 birds being 404:100, which may explain the frequency of courtship activities.

The courtship procedure has been well described by Hochbaum (1944) and Allen as quoted by Bent (1923). Although males of this species frequently followed the female in flock pursuit about the basalt-lined lakes they inhabited, they also often milled about in one place with the males slowly swimming around the female (fig. 1D, foreground). The typical action of the males in either case was the head-throw (fig. 1D, right foreground), accompanied by a sound which has been described by Allen as ick, $i c k$, cooo. At a distance this last note sounded like distant dogs baying, or turkeys gobbling, and it had a peculiar quality which is confusing in that it sounds much farther away than it actually is. Sometimes one or more of the males appeared to tire of the chase and tucked the head under a wing (fig. 1D, center foreground), as though he were taking a short nap. However, none of the males approached the female too closely, for she assumed a threat position (fig. 1D, center foreground) preceding vigorous pecking at the male. Foraging was resumed (fig. 1D, left background) following a period of courtship activity.

Aythya collaris. Ring-necked Duck.-Courtship was observed three times in the period from March 23 to April 14. Most females paired in April, although the sex-ratio was highly unequal throughout the migration period and courting parties usually consisted of four or five males per female. The sex-ratio based on 481 birds was 163:100. 


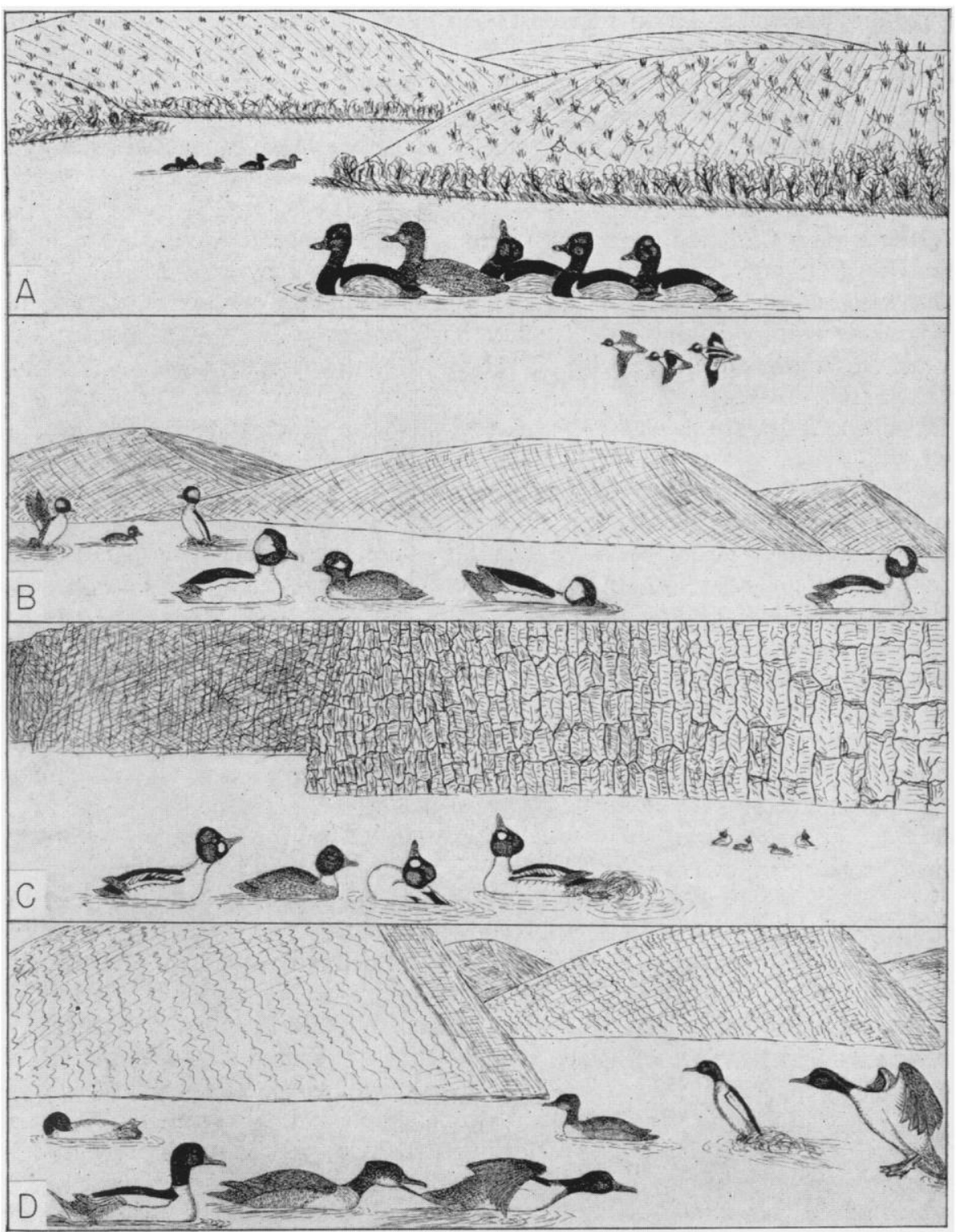

Fig. 2. Courtship mannerisms of the Ring-necked Duck (A), Bufflehead (B), Common Goldeneye (C), and Common Merganser (D).

Little has been published regarding the courtship of the Ring-necked Duck; the short description by Audubon (1840) is the only one known to me. The observations of March 29 are fairly typical. Fourteen males and four females were swimming in a small pothole. Each of the females lead a separate group of males. The males swam closely about the female, some of them with neck extended and occipital feathers raised to produce a curious angular effect (fig. 2A, foreground). This action produced a strikingly different profile from that presented under normal conditions (fig. 2A, right 
foreground). The female showed no return response, except occasionally to swim ahead with a burst of speed. The males produced a sound best described as a high-pitched, mellow cheeping, much as might be expected from a song bird. Audubon (1840) described it as "the sound produced by a person blowing through a tube." The males sometimes indulged in wing-flapping; occasionally a head-throw was observed (fig. 2A, center foreground), and they often fought with one another.

Aythya affinis. Lesser Scaup.-Courtship was observed on ten occasions, from March 15 to April 19. Most females were paired during April, although courtship was intense throughout the entire period. The sex-ratio, based on 1861 birds, was 305:100.

Published accounts of the courtship activities by Audubon (1840) and Wetmore (1920) are somewhat sketchy; K. H. Gehrmann (unpublished MS) gives a detailed account. The procedure is similar to that in other species of this genus, a single female leading three or four males on a lively chase across the lake, interspersed with erratic flights of varying lengths. The female often raises her head threateningly to nearby males, but usually allows a single male to swim beside her. The males therefore make every effort to achieve this position, and often fight among themselves. Occasionally the female dives, followed by all the males, and the group reappears some distance away. Sometimes the female is observed to raise and lower her bill rapidly in the manner described by Wetmore (1920). He described the call of the male at this time as a low whistle, the female producing a rattling, purring call; I was never close enough to the birds to hear any calls.

Bucephala albeola. Bufflehead.-Courtship was observed on 15 occasions, from February 18 to April 25. Most adult females were paired by the end of March, but immature birds actively engaged in courtship during most of the time the species was present in the area. The sex-ratio for the period, based on 474 birds, was 89:100. Probably it approached 100:100, as some immature birds doubtless were mistaken for females at long distances. The ratio of 185 birds from February 15 to March 28, before immatures became common, was 103:100.

Bent (1925) presents a colorful description of the courtship of this species; my observations are somewhat similar. The most striking feature of the display is the puffedout head feathers (fig. 2B, left foreground), which cause the white area of the head to be enlarged considerably over the normal condition (fig. 2B, right foreground). Two characteristic sequences of actions are to be noted. The more common one consists of the male swimming rapidly low in the water, with the bill on the surface and the posterior portion of the body raised, alternately extending and jerking back its head and neck, as though it were pulling itself along in the water (fig. 2B, center foreground). Sometimes a male assumes this postion as a threat attitude, facing and swimming toward his opponent. Occasionally as it nears the rival male it silently and gracefully submerges, completing the attack under water. If the intended victim is unaware of this impending attack, it swims unconcerned until suddenly it explodes into the air amid a flurry of wings and water with the victorious male emerging from below.

The second characteristic sequence is as follows: a head-dip, followed by a wingflapping, then a rapid bow similar to that of a Green-winged Teal, ending with a resounding slap of the wings against the side of the body. Male Buffleheads frequently make short flights between the various females, alighting with a splash and sliding to a stop in front of the hen, clearly showing off their white undersides (fig. 2B, left background). Courting flights (fig. $2 \mathrm{~B}$, right background) are often indulged in by this species.

Bucephala clangula. Common Goldeneye.-Courtship was observed on 15 occasions, from February 15 to April 19. It was difficult to determine the period and extent of 
pairing, as courtship continues after actual pairing takes place. The sex-ratio for this species seemed fairly even, that of 885 birds being 116:100. As in the Bufflehead, immature males are easily confused with females at any great distance, which circumstance tends to even out the apparent ratio. The sex-ratio for the period from February 15 to March 28, before immatures were common, and based on 715 birds, was 124:100; this ratio is probably more accurate than the one for the total population.

Courtship of this species is a conspicuous and fascinating display, which has been well described by Townsend (1910) and others. Goldeneyes have developed the headthrow to its extreme, throwing the head back so vigorously that the posterior half of the body becomes completely submerged (fig. $2 \mathrm{C}$, center foreground); at the same time they utter a double note, zzee-at, which in quality reminds me of the cry of a Nighthawk (Chordeiles minor). The head is then rapidly brought forward to its normal position, or perhaps more commonly to about a forty-five degree angle. The bird holds this position, with neck extended, for several seconds (fig. 2C, left foreground). A second typical action is a partial head-throw, where the head is rapidly jerked upward to a position directly perpendicular to the water, usually accompanied by a frenzied kick that splashes water far behind (fig. $2 \mathrm{C}$, right foreground). The female pays little attention to this activity. Occasionally she dives, whereupon she is followed by the entire group of males.

Males frequently fight among themselves, and sometimes they surprise-attack one another under water, in the same manner as described for the Bufflehead. Goldeneyes often are occupied in courtship displays, and rarely is it necessary to watch a group of these birds long before courting is observed. In fact, goldeneyes often serve as an impetus for nearby ducks of other species, such as Redheads, Canvasbacks, and Buffleheads, to begin courtship proceedings.

Bucephala islandica. Barrow Goldeneye.-Courtship was observed once, on March 26. The earliest arrival was on March 16 (Allen Greene, personal correspondence) at Lake Lenore, where the species breeds. This species is less common in this region than the Common Goldeneye, and courtship actions were noticeably different. Most birds observed were unpaired. Munro (1918) described the courtship of this species in British Columbia. Sex-ratio data are limited, that of 40 birds being 186:100.

Oxyura jamaicensis. Ruddy Duck.-Courtship was not observed by the writer, but it was noted on Turnbull National Wildlife Refuge, Spokane County, on May 15 by Irven O. Buss (personal communication). The species is an abundant migrant, but paired birds were not observed until May 12. The sex-ratio, based on 1044 birds, was 142:100. The first territorial birds were noted in late May.

Several writers, including Wetmore (1920), Bailey (1919), and Kortright (1943), have described the courtship performance. Territorial defense actions, observed from June 13 through July, were similar to those described by Bent (1925) under courtship activities.

Mergus merganser. Common Merganser.-Courtship was observed on four occasions, between February 24 and March 11. Copulation was witnessed on March 7. Most birds were paired by mid-March, but actual pairing was never evident. Sex-ratios changed greatly as the season progressed. The ratio for the entire period of migration, based on 615 birds was 161:100. The ratio for the period from February 15 to March 28 (479 birds) was 228:100, and for the period from March 29 to May 16 (136 birds) it was 51:100. This probably is due to differential migrations of sexes and ages. Young males of this species may be easily mistaken for females.

My observations of the courtship are similar to those of Townsend (1916). Courtship was carried out on Potholes Reservoir, sometimes far from shore. This, added to 
the wariness of the species, made observations difficult. On one occasion it was possible to drift in a boat near a courting party, in line with the setting sun. Four males and one female were in the nearest group. The males swam rapidly past the female, tails slightly raised and spread (fig. 2D, left foreground). A throaty, gargling noise was given, which Townsend (1916) attributed to the male, but which seemed to me to be emitted by the female. The female was aggressive toward the males, jabbing the nearest with her needle-like bill (fig. 2D, center foreground).

Males of this species, as well as of most others, spend considerable time preening. Usually they lie on their sides, and display their brightly colored feet and immaculate undersides to the nearest female (fig. 2D, left background).

On one occasion courting birds were observed at a great distance. Several males flew toward a female, landing and skidding over the water for 20 to 30 feet (fig. 2D, right foreground), ending the run with a dive. The procedure resembled the courtship of the Western Grebe (Aechmophorus occidentalis), and the angle of the body suggested that the bird's feet probably are similarly used to propel the body forward.

The actions during and following copulation were similar to those described for Mallards.

Audubon, J. J.

\section{LITERATURE CITED}

1840. The birds of America (New York and Philadelphia), $256 \mathrm{pp}$.

Bailey, F. M.

1919. A return to the Dakota lake region. Condor, 21:3-11.

Bennett, L.

1938. The blue-winged teal. Its ecology and management (Aimes, Iowa, Collegiate Press Inc.), $144 \mathrm{pp}$.

Bent, A. C.

1923. Life histories of North American wild fowl, order Anseres (Part 1). Bull. U.S. Nat. Mus., 126:1-250.

1925. Life histories of North American wild fowl, order Anseres (Part 2). Bull. U.S. Nat. Mus., 130:1-376.

Hochbaum, H. A.

1944. The canvasback on a prairie marsh (Baltimore, Md., The American Wildlife Institute), $201 \mathrm{pp}$.

Kortright, F. H.

1942. The ducks, geese, and swans of North America (Washington, D. C., The American Wildlife Institute), 476 pp.

Millais, J. G.

1902. The natural history of the British surface-feeding ducks (London), xiv $+107 \mathrm{pp}$.

Munro, J. A.

1918. The Barrow golden-eye in the Okanagan Valley, in British Columbia. Condor, 20:3-5.

Townsend, C. W.

1910. The courtship of the golden-eye and eider ducks. Auk, 27:177-181.

1916. The courtship of the merganser, mallard, black duck, baldpate, wood duck, and bufflehead. Auk, 33:9-17.

Wetmore, A.

1920. Observations on the habits of birds at Lake Burford, New Mexico. Auk, 37:221-247.

Department of Zoology, State College of Washington, Pullman, Washington, July 27, 1954. 